\title{
Invertebrate welfare: where is the real evidence for conscious affective states?
}

\author{
Georgia J. Mason
}

Animal \& Poultry Science Department, University of Guelph, Guelph, Ontario N1G 2M7, Canada

My paper discussing the benefits of a comparative approach to studying captive animal welfare [1] focused on vertebrates because most captive species are vertebrates; their responses to captivity are well studied; and birds and mammals have neuroanatomies and behavioural responses consistent with having some forms of conscious affective state, e.g. abilities to feel pain and fear [2]. These abilities to suffer make considering their well-being legitimate, and ethically important. Carere and colleagues [3] are right that using comparative approaches to identify causes of variation in invertebrates' captive performance could help improve their management (such methods could similarly help improve the success with which plants - and other taxonomic groups - are cultivated). However, Carere and colleagues also argue that this is important for reducing invertebrate suffering. As evidence that invertebrates can suffer, they report impressive displays of cognitive ability, especially in Octopus; the similarity of neuroendocrine stress responses across animal phyla; and that many invertebrates show responses to tissue-damaging stimuli that are consistent with pain (for similar arguments see [3]). But is this true evidence for conscious affective states? Impressive problem-solving and stimulus recognition skills are not evidence for abilities to suffer: if they were, we would worry about the well-being of computers. Furthermore, this holds true even if such abilities do indeed reveal primary consciousness ('sentience') as some argue (e.g. [4]). This is because sentience is necessary, but not sufficient, for conscious affective states to occur. Good evidence for conscious affective states should come specifically from responses to stimuli that elicit approach and positive reinforcement, or avoidance and negative reinforcement, since in humans, and perhaps other homeotherms, these give rise to positive and negative feelings. Furthermore, these responses must be ones that homeotherms demonstrably need consciousness for.

If fully-anaesthetized vertebrates can be assumed not to be conscious, we can use their reactions to this type of stimulus to identify responses that do not require conscious feelings. If we also assume that in vertebrates, conscious affective states emerge within the brain, then, similarly, responses that can occur without involvement of the brain can be ruled out as indicating consciousness. Physiological stress responses to tissue damage in humans and other mammals occur during surgery, despite subjects being under deep anaesthesia [6]. Furthermore, in humans, specific types of incision or analgesic regime that reduce reported subjective feelings of post-operative pain,

\footnotetext{
Corresponding author: Mason, G.J. (gmason@uogeulph.ca).
}

often leave patients' post-operative physiological stress responses undiminished [2]. Thus on their own, neuroendocrine stress responses to tissue-damaging stimuli are not signs of conscious suffering. The same is true for avoidance reactions to potentially harmful stimuli. Cats and rats that have been spinally transected so that their hindlimbs and rump are disconnected from the brain, will still withdraw their back feet or tails from electric shocks, and show hindlimb stepping actions when the tail is pinched [2]. Spinally transected rats can even learn to avoid painful stimuli and elevate their hindlegs for progressively longer periods of time to avoid shocks [2]. Furthermore, fully anaesthetized rats can also learn some associations, for instance the pairing of a tone with electric shock [7]. Thus the withdrawal responses and simple associative learning often argued as signs that invertebrates can experience states like pain [3-5] are not actually sufficient evidence for inferring conscious affective states.

The function of conscious affective states in homeotherms is controversial, but many argue that they mediate certain forms of flexible behavioural decision-making, such as motivational effects (modifying the strengths of competing appetitive behaviours according to their relative costs and benefits), and types of goal-seeking/harmavoidance that require innovation or planning $[8,9]$. If this is correct, to date a few invertebrate cases do potentially 'fit the bill'. For instance, octopuses (species unspecified) anecdotally show high behavioural flexibility when trying to predate a hermit crab whose shell is armed with a stinging anemone [5]; jumping spiders (Portia spp.) plan routes towards their prey [10]; and hermit crabs (Pagurus berhnardus) show evidence of motivational trade-offs during shell choice [11]. Furthermore, if their brains are implanted with electrodes, garden snails (Helix aspersa) will learn to displace a lever, an action new to their behavioural repertoire, to stimulate those neural regions involved in sexual behaviour [12]. None of these represent concrete evidence of conscious emotion, but they at least suggest that if cephalopods are to now be protected across Europe, then arachnids, decapod crustaceans and gastropods should be too. However, for the tens of thousands of other invertebrate species, including the microscopic (e.g. zooplankton) and the sessile (e.g. coral polyps and sponges) there is no evidence of conscious affective states, and most probably have neither the nervous systems to generate these nor the types of lifestyle that require them.

\footnotetext{
References

1 Mason, G.J. (2010) Species differences in response to captivity: stress, welfare and the comparative method. Trends Ecol. Evol. 25, 713-721
} 
2 National Academies, ILAR., Pain Working Group (2009) Recognition and Alleviation of Pain in Laboratory Animals, The National Academies Press

3 Carere, C. et al. (2011) Species differences in captivity: where are the invertebrates? Trends Ecol. Evol. 26, 211

4 Sherwin, C.M. (2001) Can invertebrates suffer? Or, how robust is argument-by-analogy? Anim. Welf. 10, S103-S118

5 Mather, J.A. (2008) Cephalopod consciousness: behavioural evidence. Conscious. Cogn. 17, 37-48

6 Desborough, J.P. (2000) The stress response to trauma and surgery. $\mathrm{Br}$. J. Anaesthes. 85, 109-117

7 Edeline, J-M. and Neuenschwander-El Massioui, N. (1988) Retention of CS-US association learned under ketamine anaesthesisa. Brain Res. 457, 274-280
8 Dolan, R.J. (2002) Emotion, cognition, and behavior. Science 298, 11911194

9 Rolls, E.T. (1999) The Brain \& Emotion, Oxford University Press

10 Tarsintano, M. and Jackson, R.R. (1997) Araneophagic jumping spiders discriminate between detour routes that do and do not lead to prey. Anim. Behav. 53, 257-266

11 Elwood, R.W. and Appel, M. (2009) Pain experience in hermit crabs? Anim. Behav. 77, 1243-1246

12 Balaban, P.M. and Maksimova, O.A. (1993) Positive and negative brain zones in the snail. Eur. J. Neurosci. 5, 768-774

0169-5347/\$ - see front matter ( $\odot 2011$ Elsevier Ltd. All rights reserved.

doi:10.1016/j.tree.2011.02.009 Trends in Ecology and Evolution, May 2011, Vol. 26, No. 5

\section{Art and illusion}

The Artist and the Scientists: Bringing Prehistory to Life by Peter Trusler, Patricia Vickers-Rich and Thomas H. Rich. Cambridge University Press, 2010. £27.99/US\$48, pbk (320 pages) ISBN: 9780521162999.

\section{Henry Gee}

Biological Sciences, Nature, the MacMillan Building, Porters South, Crinan Street, London N1 9XW, UK

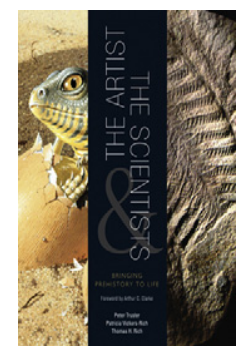

The artifice of the human world is something we take for granted. The bowl into which you pour your cornflakes of a morning, the spoon, the cup whence you sup your coffee, even the precise size and shape of the carton of milk, right down to the tiniest details of the replaceable cap, all have been designed. If one can never fail to be startled by such a revelation, then the designers of our world have done their job well. No more is this true than for art. Not necessarily the fine art that advertises itself as such (for if such art has its purposes, they can usually be discerned), but the graphic art that surrounds us; art that seems, on its surface, to be reportage, a portrait of reality. What is more, the closer to reality it appears, the greater the artist's skill not as reporter, but as illusionist.

Peter Trusler is a skilled natural-history artist who has been working closely with palaeontologists Patricia VickersRich and Thomas H. Rich for more than 30 years. Rather than just using photographers (although they have these, too), the palaeontologists have employed Trusler's artistic eye to document the fossils that they find, both as pure reportage, and to bring the many fossil forms to life. The Artist and the Scientists is a series of portfolios, as artist and scientists tackle a range of projects, from the detailed depiction of a few fossil specimens, to the restoration of extinct forms in life-like poses for use in everything from research papers to exhibition catalogues and postage stamps.

For the artist, there is no one-size-fits-all approach. Each project creates its own questions. The most obvious are those posed by commissions in which the artist has to reanimate fossils of extinct creatures, such as the Precambrian

Corresponding author: Gee, H. (h.gee@nature.com).
Ediacara fauna, that have no modern counterparts and no models. Such undertakings demand a great deal of detective work, as the artist assembles every possible scrap of information that might bear on the subject. Trickier, however, is when an artist has to bring dinosaurs back to life. Everyone thinks that they know what dinosaurs were like, and yet any such impressions are created not by real life (for, believe it if you can, nobody has ever seen a dinosaur alive) but by layer upon layer of artistic reconstruction, some of which draw on the most inappropriate models. Why, asks Trusler, do dinosaur-obsessed film-makers have their creations roar like lions and bears? Is there any justification for this? Or are artists driven, perhaps, by deeper rooted cultural imperatives? Might it not be better for dinosaurs to squawk like chickens, or perhaps make no noise at all? As the man said, whereof one cannot speak, thereof one should be silent.

I was surprised, however, that such considerations preoccupy artists who are being asked, simply, to record what they see in front of them, be it a tooth, or a scrap of bone. That the camera has not killed such purely representational art is a testament to its necessity. It is probably a caricature to say that drawing is to photography what reading is to photocopying, but perhaps the best way to get to know a specimen is to draw it. Palaeontologists must be good draughtsmen. I spent the first few weeks of my $\mathrm{PhD}$ project as a trainee palaeontologist working on fossil bison and cow bones, doing nothing but drawing bones: every single element of the skeleton of Daisy the Cow, from all different angles. No amount of photography could have trained me in the recognition of bones, their shapes, their heft, their surface details or their 'boneness'. It is the insight brought by such painstaking work that makes Trusler very much the equal of the scientists he serves. 